By KAROL MAICHEL

\title{
Bibliographical Guides to Russian Periodical Publications, 1901-1956
}

$\mathrm{O}$ NE OF THE MAIN bibliographical problems in Russian scholarship is the lack of a complete, general, retrospective bibliography of Russian periodical publications of the twentieth century. ${ }^{1}$ This paper intends to familiarize the librarian with the most useful bibliographical works on Russian periodical publications covering this period. If not otherwise indicated, the bibliographies given list all material published on a periodic (or regular) basis, i.e., journals, newspapers, bulletins, etc.

Up to 1949 , there was no work completely covering the prerevolutionary period of the twentieth century. In that year, the Saltykov-Shchedrin Public Library published the Predvaritel'nyi spisok periodicheskikh izdanii Rossii 1901. 1916 godov, ${ }^{2}$ under the editorship of Iu. A. Mezhenko. This work attempted a complete coverage of the periodical press for the first sixteen years of the twentieth century. It lists 14,362 items (journals, newspapers, bulletins, collections) by place of publication, beginning with St. Petersburg and Moscow, with the other cities following in alphabetical order. Within the category of each

1 The eighteenth and the nineteenth centuries are well covered in the following three works: N. M. Li sovskii, Russkaia periodicheskaia pechat'. 1703-1900 V. I. Sreznevskii, Spisok russkikh povremennykh izdanii. 1703-1899. and A. N. Neustroev, Istoricheskoe rozyskanie o russkikh povr. N. Neustroev, Istoricheskoe $1802 \mathrm{gg}$, from which Lisovskii's work is the most $1802 \mathrm{gg}$, from which Lisovskii's work is the most see N. V. Zdobnov, Istoriia russkoi bibliografii do nachala $X X$ veka, 3rd ed., Goskul'tprosvetizdat, Moscow, 1955, pp. 407-411.

${ }^{2}$ Preliminary list of Periodical Publications in Russia 1901-1916. (Leningrad, 1949, 306p. At head of title: Gos. Publichnaia biblioteka im. M. E. SaltykovaShchedrina.)

Mr. Maichel is Slavic Librarian, Columbia University Libraries. city, material is listed in alphabetical order, and the description of each item generally includes title, year of publication, change of title (if any), supplements, periodicity, and place of publication. At the end of the work there is an alphabetical index of titles, not including those published in St. Petersburg and Moscow, as well as an alphabetical index of places of publication.

The Predvaritel'nyi spisok was based on material in the Soviet libraries, as well as on various bibliographical registrations. Since only 3,500 items or so were verified de visu, all but these 3,500 are numbered 1,2 , or 3 , to indicate the validity of the source, the numeral 1 indicating the highest reliability, 3 the least. ${ }^{3}$ Since this work has not been published for general consumption, serving as its title indicates, as a preliminary list which will eventually be revised and enlarged into a six-volume work, only a very few American libraries possess copies. Because of this, and because it does not have a chronological index - the importance of which, of course, cannot be overstressed-the librarian will generally be forced to turn to the numerous annual bibliographies covering this period. The best of these are outlined below.

On April 5, 1865, the Chief Administration of Printed Works ${ }^{4}$ took charge of censorship, and in this capacity began the official registration of Russian

\footnotetext{
${ }^{3}$ Although a most commendable work, it lacks completeness. A more detailed critical evaluation of this work can be found in A. V. Velizheva's article "Bibliografiia periodicheskikh izdanii" in Sovetskaia Bib. liografiia, 43 (1956), 10-17. liografia, 43 (1956), $10-17$.
\& Glavnoe Upravlenie po Delam Pechati.
} 
book output. ${ }^{5}$ A list of books published was put out annually; a periodical list was published irregularly, and under various titles, until 1889. From 1889 to 1905 , this list was published as Spisok periodicheskikh izdanii $v$ Rossiiskoi imperii, za iskliucheniem vykhodiashchikh v svet $y$ Finlandii. ${ }^{6}$ During this period, the list was published in 1889,1891 , 1894, 1899, 1900, 1901, 1903, and 1905, and, except for 1905, always appeared first in the various numbers of Pravitel'stvennyi Vestnik, ${ }^{7}$ and was later put out in individual reprints. The arrangement, beginning with 1882 , is by place of publication, beginning with St. Petersburg and Moscow, and continuing with the provinces in alphabetical order. Within each of these geographical categories, material was arranged according to language, and beginning with those in Russian. The description of each item is detailed, including title, subtitle, editors, year of publication, periodicity, supplements, and price.

However, this series does not completely cover periodical output for the first five years of the twentieth century, and other guides must be consulted. One of the best of these is found in A. Suvorin's Russkii Kalendar', 8 which, from 1873 to 1905, included an annual list of periodicals published under the heading "Periodicheskie izdaniia."9 $\mathrm{Al}$ though Suvorin's list is far from complete, it nevertheless covers a number of titles omitted by the publication of the Chief Administration of Printed Works, and thus can serve as its supplement. Experimenting at first with various annual arrangements, "Periodicheskie izdanii," in the twentieth century, ar-

\footnotetext{
5 For information on book registration by the Glavnoe Upravlenie po Delam Pechati see N. V. Zdobnov op. cit., pp. 369-376.

${ }^{6}$ List of Periodical Publications in the Russian Empire, except those published in Finland. ("Pravitel'stvennyi Vestnik" St. Petersburg, 1889-1904.) (List for 1905 was published by tip. Ministerstva Vnutornfor 1905 was pub
nikh Del, 1906.)

nikh Del, 1906.)

8 The Russian Calendar.

- Periodical Publications.
}

ranged titles alphabetically by place of publication.

A direct continuation of these two works is found in D. V. Val'denberg's Spravochnaia kniga o pechati, ${ }^{10}$ under the title "Perechen' povremennym izdaniiam, na vypusk v svet koikh v S.-Peterburge vydany, po 1 noiabria 1906 goda ..."11 Val'denberg lists, in alphabetical arrangement, the periodical publications appearing toward the end of 1905 and through 1906 . The bibliographical information given is comparatively short, but is extremely useful in that it notes issues confiscated by the official censorship of the time.

There are no annual bibliographical listings for 1907. The year 1908 is covered in A. D. Toropov's "Spisok povremennykh izdanii, vykhodivshikh $\mathrm{v}$ svet $\mathrm{v}$ 1908 godu,"12 which appeared in The $A l^{\prime}$ manakh pechati na 1909 g. Sbornik svedenii o vsekh periodicheskikh izdaniiakh. ${ }^{13}$ This work lists over 1,500 items, arranged by language and in alphabetical order. According to what is currently known of the periodicals published in 1908, Toropov covers approximately 85 per cent of those published in Russian, and only about 50 per cent of those published in other languages.

There are no satisfactory bibliographical listings for 1909. The following three years, however, are quite adequately covered in the works of A. V. Val'denberg, A. V. Vol'fson, and I. V. Vladislavlev.

Val'denberg's work is entitled "Periodicheskie izdaniia vsei Rossii," 14 appearing in his book Spravochnaia kniga o pechati usei Rossii, ${ }^{15}$ and covers the years 1910 and 1911. This work is ar-

10 Handbook of the Press (St. Petersburg, 1907, pp 75-133).

11 List of Periodical Publications, published in St. Petersburg, up to November 1, 1906.

12 List of Periodical Publications, published in 1908.

13 Press Almanac for 1909. Collection of information about all periodical publications. (St. Petersburg, 1909, pp. 1-120.)

is Periodical Publications of All Russia.

15 A Handbook of the Press of All Russia (St. Petersburg, 1911, pp. 514-81). 
ranged in alphabetical order by place of publication, and alphabetically by language within each of these geographical groupings. Altogether, it lists over 2,000 items.

Vol'fson's work is entitled "Periodicheskie izdaniia, vykhodiashchie v Rossii na vsekh iazykakh,"16 and covers the years 1910 and 1912. The year 1910 is covered under the above title in the first edition of Vol'fson's Adresnaia i spravochnaia kniga-Gazetnyi Mir-na 1911 god,17 where 1817 items are listed. The second edition of this book, published two years later, listed 2,167 items for 1912. Both of these lists are arranged in alphabetical order by place of publication, headed by St. Petersburg and Moscow. Within each of these categories, items are listed by language, beginning with Russian and continuing with the other languages in alphabetical order. Both lists give brief bibliographical information and are indexed by language and by subject.

In "Periodicheskie izdaniia, vykhodiashchie v Rossii na russkom iazyke,"18 which appeared each year in his Bibliograficheskii Ezhegodnik ${ }^{19}$ (published annually from 1912 to 1915), Vladislavlev listed journals and newspapers in the years 1911-1914. However, Vladislavlev included only that material which he felt to be of importance, and the listings are therefore incomplete. For the years 1911 and 1912, they are of no practical value, since Val'denberg and Vol'fson covered this period much more extensively. For 1913 and 1914, despite Vladislavlev's selectivity, his listings are indispensable, since we have no other annual listings of periodicals for those years. Items are listed, in this work, in four major categories, according to the type of publication.

\footnotetext{
16 Periodical Publications, appearing in Russia in all languages.

17 Directory and a Handbook of The Newspaper World for 1911. (St. Petersburg, 1910, col. 17-339); ( $2 \mathrm{n}$ ed., 1912, col. 25-533.)

18 Periodical Publications, appearing in Russia in the Russian language.

1o Bibliographic Annual.
}

Vladislavlev's work has an additional importance. Each year, under the subheading 'Ukazatel' konfiskovannykh izdanii," 20 he listed those journals and newspapers confiscated by the official censorship bureau.

Again, there are no satisfactory bibliographical listings for 1915. The year 1916 is covered in a work entitled Spisok povremennykh izdanii, vykhodiashchikh v Rossii v 1916 godu, ${ }^{21}$ which was published by the Chief Administration of Printed Works. Altogether it lists 1,480 items, which are arranged alphabetically according to language, beginning with Russian.

The years 1908-1917 are also partially covered in the Knizhnaia Letopis'22 under the title "Letopis' povremennoi pechati."23 This section of the Knizhnaia Letopis' appeared in almost every weekly issue, and attempted to list only the periodical publications put out for the first time, and those which had changed their titles. Thus, these inadequate listings are the sole annual guides for the years 1909 and 1915 .

In addition to all the works already mentioned, the period $1900-1916$ is also covered in the work of I. A. Kubasov, who, in 1912 published his first list of periodical publications issued by the Academy of Sciences. This list, entitled Katalog izdanii imperatorskoi Akademii nauk. (Ch. 1.) Periodicheskie izdaniia, sborniki, otchety $i$ serii, ${ }^{24}$ covers the period from 1726 to June 1, 1912. Four supplements were subsequently published which brought the work up to December, 1923.

No comprehensive guide to periodical

${ }^{20}$ Index of Confiscated Publications.

21 List of Periodical Publications, published in Russia in 1916.

${ }_{22}$ Book Annals (For detailed information on the history of Knizhnaia Letopis' see T. J. Whitby's article "National Bibliography in the USSR" in $L i$. brary Quarterly, XXIII (1953), 17-19, as well as M. V. Sokurova, Bibliografiia Russkoi Bibliografi, M. V. Sokurova, Bibliografiia Ruad, 1944 , v.1. pp. 143-164.)

${ }_{23}$ Annals of Periodical Publications.

${ }_{24}$ Catalogue of the Publications of the Academy of Sciences. (Part 1.) Periodical Publications, collections, reports and series . . . (St. Petersburg. Akademiia Nauk, 1912. 148p.). 
publications exists for the period after 1917 , but, if the plans outlined by the All-Union Book Chamber ${ }^{25}$ are fulfilled, we will have such a guide within a year. In 1955, this agency published the third volume (the first to be issued) of a set entitled Periodicheskaia Pechat' SSSR. 1917-1949,26 which will eventually consist of ten volumes. The first nine of these will cover the following subjects: Vol. I-socio-political and socio-economic journals; Vol. II-journals of natural science and mathematics; Vol. Illjournals, transactions, and bulletins in the technical sciences and industry; Vol. IV_-journals, transactions, and bulletins in transportation, communications, and communal work; Vol. V-journals, transactions, and bulletins in the field of agriculture; Vol VI-journals of science, "education," physical culture, and sport; Vol. VII-medical journals; Vol. VIII-journals of linguistics, literary criticism, and art; Vol. IX-journals related to the fields of publishing, library science, and bibliography. The tenth volume will be a comprehensive index to the other nine. Thus far, three have been published-Volumes III, IV, and V. The rest are scheduled for publication by the end of 1957 .

On the basis of the three volumes that have already appeared, several things can be noted:

The arrangement is classified. Within each group, material is divided into types of publications-e.g., journals, bulletins, transactions-and within each of these subdivisions the items are listed in alphabetical order by title. If the title of any journal has undergone a change, the entry is made under the latest name with cross-references to previous titles. Materials published in languages of the Soviet Union other than Russian are listed in Russian translation,

\footnotetext{
${ }^{25}$ Vsesoiuznaia Knizhnaia Palata (which is the governmental agency charged with the unification and coordination of bibliographical activities throughout the U.S.S.R.).

${ }_{26}$ Periodical Press of the USSR 1917-1949.
}

with the original name also transliterated.

The bibliographical information for each item is quite detailed, including title, sub-title, place of publication, publisher, year of publication, supplements (if any), indexes, explanatory notes.

Each of the volumes has its own indexes: (a) alphabetically by titles; (b) an alphabetical index of journals in languages other than Russian; (c) a geographical index; d. an index by publishing house.

The value which this set will have for librarians when completed cannot be overstressed. It is unfortunate, however, that it will not include newspapers, since I know of no work being planned that fills this gap in Russian bibliography. There are, of course, bibliographical works which list newspapers over a period of years, but they are not complete, and cannot take the place of a really comprehensive work. The only even partially comprehensive work of this sort is H. Horecky's Russian, Ukrainian, and Belorussian Newspapers 1917. 1953. A Union List, which was published by the Library of Congress in 1954. This work indicates the locations of newspapers in the three languages indicated in the title, in American libraries. Horecky does not indicate the actual quantity of material in any one library, but indicates by symbols the percentage of issues each library has out of the total published in a given year. The material is listed in alphabetical order by place of publication, with items listed alphabetically within each category. An alphabetical index of titles and a guide to places of publication are included.

This work was preceded by a Preliminary Checklist of Russian, Ukranian, and Belorussian Newspapers Published Since January 1, 1917, Within the Present Boundaries of the USSR and Preserved in the United States (a Working 
Paper). ${ }^{27}$ Published in 1952, it lists chiefly newspapers which are available in the collections of the Library of Congress.

Another work which may be used as a guide to the period covered by Horecky is the Ukazatel' Sovetskoi Periodicheskoi Pechati, ${ }^{28}$ which was published in 1954 , in Munich, by the Institute for the Study of the History and Culture of the USSR. This work lists 1,208 periodical publications, largely newspapers. It is divided into three groups: (1) newspapers, (2) journals, and (3) newspapers and journals published in Russia, either in Russian or in other European languages, and intended for foreign use. The first of these groups, consisting of 670 items, is subdivided into such categories as general newspapers, newspapers of the various Soviet Republics, etc., and has its own alphabetical index. The second group is arranged in alphabetical order by title, and the third is subdivided by language, with the items listed alphabetically. On the whole, of course, this work gives a poor representation of the total Soviet output, but has some usefulness as a guide to newspapers. The bibliographical information is very sketchy, listing title, place of publication, language of publication, and, in some cases, the first year of publication, and periodicity.

Until the Periodicheskaia Pechat'. 1917-1949 is completed, therefore, we shall have to turn once more to those bibliographies which cover several years of this period, at most. These bibliographies will have their value as chronological guides to periodical output even after the completion of the Periodicheskaia Pechat'. 1917-1949, since that work, though most comprehensive, does not have a chronological index.

The first two years of the Soviet period

${ }^{27}$ Compiled by Paul L. Horecky. The Library of Congress, Washington, 1952.97p.

28 Index of the Soviet Periodical Press. (Munich, 1954. 151p.) (Published in the intitute's series "Is" sledovaniia i materialy" Seriia II, No. 12.) are best covered in L. K. Il'inskii's Spisok povremennykh izdanii za 1917 (1918) god..$^{29}$ the first volume of which, covering the year 1917, was published in 1919, and the second of which, covering the year 1918, was published in 1922. This work has an alphabetically arranged listing of journals, newspapers, bulletins, transactions, etc. which were published in Russia, both in Russian and other languages, in the period 1917-1918. NonRussian material is listed in Russian transliteration. Volume I has no index, while Volume II has both a geographical index and an index by editor and publisher. Both volumes together list a total of approximately 7,000 items, thus covering about 75 per cent of the Russian output in those years. The work is weakest in its coverage of provincial publications.

The year 1919 is covered in only one work, entitled Ukazatel' No. 1 periodischeskikh Sovetskikh $i$ Kommunisticheskikh izdanii, vykhodiashchikh v RSFSR $1919 \operatorname{god}^{30}$ which was published by the National Commissariat of Post and Telegraphs. ${ }^{31}$ This work lists 318 journals and newspapers published in the RSFSR. in Russian and other languages. The material is arranged in alphabetical order by place of publication and, though not complete, is of great importance, since it is the only existing guide to 1919.

The years 1917, 1918, 1920-1922, and 1924-1926 are covered in the already mentioned Knizhnaia Letopis'. In 1917, only new and changed titles were listed, as has been already pointed out. Beginning with 1918, Knizhnaia Letopis' listed all the periodicals received by the Knizhnaia Palata, and lists of this material appeared in practically every number of the publication. Material in Russian and other languages was listed,

29 List of Periodical Publications for 1917 (1918). (Petrograd, 1919-1922. 186, 288p.)

${ }^{30}$ Index No. 1 of Soviet and Kommunist Periodical Publications, Published in RSFSR in 1919. (Moscow, NKPT, 1919. 8p.)

31 Narodnyi komissariat pocht i telegrafov. 
arranged according to the type of publication (e.g., newspaper, journal, bulletins, etc.). Knizhnaia Letopis' continued these listings only until December, 1926, after which date they were discontinued, to be resumed much later in 1939 (and published thereafter only until 1944). Listings in this 1939-1944 period returned, interestingly enough, to the 1908-1917 system, whereby only new and changed titles were listed each year.

Besides this, the newspaper output for 1920 is covered in Gazety Sovetskoi Ros$\mathrm{sii}^{\mathbf{3 2}}$ which was published in 1921. This work is of great importance, since it is the only listing we have for the first seven months of 1920 , as the Knizhnaia Letopis' did not register the periodical publications from January, 1919 until August, 1920. This listing is divided into two parts, one of which lists material geographically, the other alphabetically.

The next years to receive bibliographical coverage are 1928 and 1929. The year 1928 is covered in a piece entitled "Zhurnaly SSSR. Gazety SSSR,"33 which appeared in Adresnaia kniga izdatel'skikh $i$ knigotorgorykh predpriiatii, zhurnalov i gazet SSSR na 1928 g., ${ }^{34} \mathrm{com}-$ piled by I. A. Tsetkin. Approximately 800 journals and 600 newspapers, published in the Soviet Union, are listed, the journals in a classified arrangement, the newspapers by place of publication. This work is particularly weak in the listing of scholarly periodicals published in the various Soviet Republics. It has two alphabetical indexes, one for journals, and one for newspapers.

The year 1929 is covered in Gazety $i$ zhurnaly SSSR. Spravochnik na 1929 god o vsekh periodicheskikh izdaniiakh, vy-

${ }^{32}$ Newspapers of Soviet Russia (Moscow: Organizatsionno-instruktorskii sektor Tsentroposta, 1921. 64 p.).

Journals of USSR Newspapers of USSR

34 An address book of publishers and book-dealers, journals and newspapers of the USSR in 1928. (4th ed. Gos. izd. Moscow-Leningrad, 1928. pp. 291.401, 405.479.) khodiashchikh $v$ SSSR,35 by A. P. Khomskii and P. S. Chekhovskoi. Approximately 1600 items are listed in this work, divided into the categories of Journals and Newspapers. The newspapers are listed by place of publication, beginning with Moscow, Leningrad and Kharkov, and continuing thereafter in alphabetical order. The journals are arranged alphabetically, by subject. An alphabetical index for each group is included.

The three years following 1929 have no bibliographical listing. In 1933, the All-Union Book Chamber began the annal listing of the periodical output of the Soviet Union. This listing was published, in 1933, under the title Spisok periodi. cheskikh izdanii RSFSR, ${ }^{36}$ becoming $L e$ topis' periodicheskikh isdanii SSSR ${ }^{37}$ in 1934, and Ezhegodnik periodicheskikh izdanii $S S S R^{38}$ in 1938. It was published under the latter title in 1938 and 1939, and was then discontinued until 1946, when it resumed under the title Letopis' periodicheskikh izdanii SSSR. In 1933, only material published in the RSFSR was listed. From 1934 on, the output of the entire SSSR was included. The arrangement of items varied somewhat from year to year, but the following generalizations can be made: from 1933 to 1939 , journals and newspapers were registered separately. Each of these groups was subdivided into the categories of Russianlanguage and non-Russian-language material. Within each of these subdivisions, from 1933 to 1937 , material was arranged in alphabetical order by title, or by publishing body. Beginning in 1938, the newspapers were arranged by place of publication, and beginning in 1939 the journals were arranged according to a new system of thirty-one subjects, within each of which items were listed alphabetically. For each item, such bibliograph-

\footnotetext{
${ }^{35}$ Newspapers and Journals of the USSR. Handbook of all periodical publications of the USSR for 1929. (Moscow, NKPT, 1929. 168p.)

${ }^{38}$ List of Periodical Publications of the RSFSR

${ }^{37}$ Annals of Periodical Publications of the USSR. USSR.
} 
ical information as year of establishment, periodicity, number of pages, format, number of copies printed, and annual subscription rate, is included. The number of indexes varies from year to year, progressing from one in 1933 (by place of publication) to nine in 1949 (alphabetically by title, by publisher, by place of publication, by subject (newspapers), plus separate indexes for material in Russian, and material in other languages).

Although most of the bibliographies discussed up to this point list official government periodical publications with varying degrees of completeness, W. Gregory's List of the Serial Publications of Foreign Governments 1815-193139 brings these together comprehensively for the first time. Gregory's List covers all foreign countries in alphabetical order except for Russia, which is given a separate listing at the very end (pp. 658-716). The Russian listing is divided into four sections: the first of these covers Imperial Russia from 1815 to 1917 , with special sub-sections for the Grand Duchy of Finland and the Kingdom of Poland; the second covers the publications of the Provisional Government (March, 1917November, 1917), listing only those which began and ended with the Provisional Government, while those which continued afterward are listed in the following two sections; the third section covers the publications of the USSR, with a separate sub-section for the publications of the Communist Party; the fourth, and last, section covers the governmental publications of the various "Soviet Republics." The titles are given first in the Russian alphabet, and then in English transliteration. The arrangement is alphabetical by government department or bureau, and, within each of these subdivisions, alphabetical by title. Gregory's List is based on the holdings of eighty-five American libraries, giving in-

\footnotetext{
${ }^{30}$ Edited by Winfred Gregory. New York, 1932. $720 \mathrm{p}$.
}

dications of their holdings, and so cannot be called complete.

The war years 1939-1944 are covered in Knizhnaia Letopis' under the title "Gazety i zhurnaly (novye i pereimenovannye)," ${ }^{40}$ which listing appeared in its various weekly issues. As was pointed out earlier, this listing includes only new and changed titles. It is divided into two parts, newspapers and journals, and the items are arranged alphabetically by title.

Because of the suspension of Ezhegodnik periodicheskikh izdanii SSSR, and in response to the pressing need for a bibliography of periodicals for this period, the reference department of the Library of Congress has published a list entitled Serial Publications of the Soviet Union 1939-1951, A Preliminary Checklist. Compiled by Rudolf Smits, it is a valuable guide which, while excluding newspapers, attempts to list all governmental and non-official serial publications in Russian and Ukrainian which appeared in the Soviet Union within the period 1939-1951. Publications in any of the minority languages of the Soviet Union were included in this list only if they had a title page and contributions in Russian. Items are arranged in alphabetical order, and the work has a subject index. If any title happens to be in the Library of Congress, the exact holdings of the Library are given, and the checklist also indicates whether titles are in any other American libraries, without giving any figures as to their holdings. This latter information is not always accurate, however.

In 1951, the All-Union Book Chamber decided to reorganize the registration of periodical publications, and to publish a complete list not annually, but every five years. In the interim between two of these complete lists, annual lists of new periodicals, periodicals which have changed their titles, and periodicals which have ceased to publish, will be

\footnotetext{
40 Newspapers and Journals (new and re-named).
} 
put out. This annual list is being published in two volumes under the title Letopis' periodicheskikh izdanii, one of which covers journals and newspapers, and the second of which covers such material as scholarly publications, transactions, irregular periodical publications, etc. The material in the first volume is arranged alphabetically, the material in the second by subject, and then in alphabetical order. Several indexes are included, depending on the type of publication.

In 1955, the first of the comprehensive five-year volumes was published, entitled Letopis' periodicheskikh izdanii SSSR, 1950-1954 gg,41 covering the period 19501954. This work is divided into two parts, journals and newspapers.

In the first of these groups, 2,922 items are listed. They are divided, first, into thirty-three subject classes, within each of which the items are subdivided by type-e.g., general journals, bulletins, almanacs, etc.

The second part lists 5,598 newspapers altogether, arranging them according to the Soviet Republic in which they are published-e.g., Ukrainian SSR, Belorussian SSR, etc. Within each of these divisions, the newspapers are further subdivided by specific districts. Newspapers which have ceased publications are listed at the end of each of these subdivisions. The bibliographical information shows title, subtitle, publisher, frequency, year of issue, imprint, language, price of individual issue, impression, change in title (if any). In case of vagueness in periodicity or if not all numbers were published, a detailed enumeration of issues published is given.

Both sections list non-Russian material in transliteration into Russian. The first has four indexes of journals: alphabetical in Russian, alphabetical by language, by publisher, and by place of publica-

41 Annual of Periodical Publications of the USSR., 1950-1954. Moscow. Vsesoiuznaia Knizhnaia Palata, 1956. $500 \mathrm{p}$. tion. The second has two indexes: alphabetical, and alphabetical by language.

In addition to all the above, there is also a bibliographical guide to the periodical publications put out by Russian émigrès. This work, Ukazatel' periodicheskikh izdanii emigratsii iz Rossii $i$ SSSR za 1919-1952 g.g., ${ }^{42}$ was published in 1953 by the Institute for the Study of the History and Culture of the USSR, in Munich. It lists 2,356 items, divided into five major categories by language-e.g., Russian, Ukrainian, White Russian, nonSlavic languages of the USSR, and Western European languages. Within each of these categories, the items are arranged in alphabetical order. The bibliographical information for each item is not always complete, since it is comparatively difficult to procure details about material which is, in many cases, put out by amateur political groups in mimeographed form, and irregularly at that. However, the attempt was made, wherever possible, to include title, editor, periodicity, years of publication, and the number of issues published. The work has an index by place of publication.

Also, it should be pointed out that the various union lists of periodical publications are of great importance, since they indicate the location of this material outside of the Soviet Union. The best of these is the Union List of Serials in Libraries of the United States and Canada, which lists the holdings of a total of six hundred libraries. Russian items are here intermixed with others in alphabetical arrangement. This Union List of Serials is of great help not only for the location of individual titles, but in the determination of what constitutes a complete set of any publication. It must always be remembered, of course, that it includes only those titles available in the libraries indexed, and that it does not include newspapers, governmental pub-

${ }^{42}$ Index to Periodical Publications from Russia and USSR emigration from 1919-1952.

(Continued on page 262) 


\section{New College Library Standards}

(Continued from page 200)

tions for 25-331/3 per cent of the student body will be suggested; allowance for differences between the residential and commuter colleges will be made. Shelf space should be provided to take care of growth for at least a decade.

Finally, the standards will urge close interlibrary cooperation along the lines suggested in A Plan for Meeting College Library Problems, the report of the Regents' Committee (Albany: State Education Department, 1954). A frequent evaluation of the library is also recommended. Library staff and teaching faculty should ascertain by joint efforts that the standards of service are high and that the library fulfills its educational tasks. This is no easy job, for how is one to measure the spirit of a library? The per capita circulation of books to students on two-week loan may offer some valuable clues; in fact, some educators, such as Henry M. Wriston, consider it the best index of an institution's intellectual health. But, owing to special local con$\Delta /$ ditions, this figure may not always provide a reliable yardstick and must, therefore, be used with considerable caution.

The ACRL Committee on Standards is well aware of the criticism that some of its proposals may provoke. New standards cannot please everybody; to do so they would have to be confined to vague generalities. The hour calls for vision and boldness. We must design standards which are high enough and flexible enough to protect and improve the position of the American college library as it faces the unprecedented challenge of the nineteen-sixties.

\section{Russian Bibliographical Guides}

(Continued from page 216)

lications, and several other categories of material. ${ }^{43}$

Another such union list is the justpublished Catalogue collectif des periodiques, ${ }^{44}$ put out by the Bibliotheque $\mathrm{Na}$ tionale in Paris, which lists the Cyrillic Slavic periodicals in the French university libraries, and in the Parisian libraries, as of 1950. The arrangement is alphabetical by title. Each entry is also provided with call numbers in the various libraries. This work was preceded by that of B. Unbegaun, ${ }^{45}$ which was pub-

13 For a detailed description of this work see: Constance M. Winchell, Guide to Reference Books, 7 th ed., Chicago, 1951. p.94.

14 Bibliotheque Nationale, Paris. Départment des periodiques. Catalogue collectif des periodiques conserves dans les bibliotheques de Paris et dans les bibliotheques universitaires de France, periodiques slaves en caracteres cyrilliques; etat des collections en 1950. Paris, 1956. 2 Vols.

${ }^{45}$ Unbegaun, Boris, Catalogue des periodiques slaves et relatifs aux etudes slaves des bibliotheques de Paris. Paris, 1929. 221p. (Published as Volume IX to Travaux publies par l'Institut d'etudes slaves.) lished in 1929. The latter lists all periodicals relating to Slavic affairs, in Slavic and other languages, available in the Paris libraries as of 1927.

In conclusion, we may say that once the Periodicheskaia Pechat' SSSR 19171949 is completed, we will have a complete registration of the periodicals of the twentieth century, up to the present time, as this work is the chronological continuation of the Predvaritel'nyi spisok periodicheskikh izdanii Rossii 19011916 , and in turn is continued by the Letopis' Periodicheskikh izdanii SSSR 1950-1954. Unfortunately this is not true of newspapers, as the Periodicheskaia Pechat' SSSR does not include these. For these, as well as for chronological guidance to periodicals, we shall still have to turn to the numerous annual bibliographies. 